\title{
Cypermethrin Etken Maddeli Bir İnsektisitin Cucumis sativus L. (Hıyar) Üzerine Morfolojik ve Fizyolojik Etkileri
}

\author{
Aylin EŞİ DEREBOYLU ${ }^{1 *} \quad$ Ulaş UĞUZ ${ }^{1} \quad$ Nedret ŞENGONCA TORT ${ }^{1}$
}

ÖZET: Çalışmada, sera koşullarında yetiştirilen hıyar (Cucumis sativus L.) bitkilerine farklı konsantrasyonlarda (Önerilen doz $=0.4 \mathrm{ml} \mathrm{L}^{-1}$ su, önerilen dozun iki katı $(\mathrm{x} 2)=0.8 \mathrm{ml} \mathrm{L}^{-1}$ su ve üç katı $(\mathrm{x} 3)=1.2 \mathrm{ml} \mathrm{L}^{-1} \mathrm{su}$ ) Cypermethrin etken maddeli bir insektisit uygulanmıştır. Morfolojik ölçümlerin yanında, çimlenme yüzdeleri, total protein ve prolin miktarları, fotosentetik pigment maddeleri ve endogen hormon içeriği de incelenmiştir. Uygulanan insektisitin tohumların çimlenmeleri üzerinde etkili olmadığı görülmüş̧ür. Ancak büyüme parametrelerinden kök uzamasını inhibe ettiği belirlenmiştir. Fotosentetik pigment maddelerinde klorofil a, $\mathrm{b}$ ve toplam klorofil değerlerinde kontrol grubuna göre x3 uygulama grubunda azalma olmuş, karotenoid değerlerinde ise artı̧̧ meydana gelmiş̧ir. Protein, prolin, Absisik asit (ABA) ve Indol-3 Asetik asit (IAA) miktarlarında kontrole göre $\mathrm{x} 3$ uygulama grubunda artışlar olduğu görülmüş̧ür. Bu sonuçlara göre; uygulanan insektisitin özellikle yüksek konsantrasyonlarda uygulanması durumunda hiyar bitkilerinde abiyotik stres yarattığı, strese bağlı olarak bitki metabolizmasını, büyümeyi ve gelişmeyi olumsuz yönde etkilediği ortaya konmuştur.

Anahtar kelimeler: Cucumis sativus L., cypermethrin, prolin, protein, stres

\section{Morphological and Physiological Effects of the Insecticide with Cypermethrin Active Substance on Cucumis sativus L. (Cucumber)}

\begin{abstract}
In this study cucumber (Cucumis sativus L.) plants grown in greenhouse conditions were treated with different concentrations (Recommended dose $=0.4 \mathrm{ml} \mathrm{L}^{-1}$ water, twice the recommended dose $(\mathrm{x} 2)=0.8$ $\mathrm{ml} \mathrm{L}^{-1}$ water and three times $(\mathrm{x} 3)=1.2 \mathrm{ml} \mathrm{L}^{-1}$ water) Cypermethrin active insecticide. In addition to morphological measurements, germination percentages, total protein and proline quantities, photosynthetic pigment substances and endogen hormone content were also examined. The insecticide applied did not seem to be effective on germination of seeds. However, it was determined that it inhibited root elongation, one of the growth parameters. Chlorophyll $\mathrm{a}, \mathrm{b}$ and total chlorophyll values decreased in $\mathrm{x} 3$ treatment group and increase in carotenoid values compared to the control group. Protein, proline, abscisic acid (ABA) and Indol-3 Acetic acid (IAA) values were found to increase in the $\mathrm{x} 3$ treatment group relative to control. According to these results; it has been determined that applied insecticide causes abiotic stress in cucumber plants especially with high concentrations. It has been shown that plant metabolism, growth and development are affected negatively by stress.
\end{abstract}

Keywords: Cucumis sativus L., cypermethrin, proline, protein, stress

\footnotetext{
${ }^{1}$ Aylin EŞIZ DEREBOYLU (Orcid ID: 0000-0002-4092-414X), Ulaş UĞUZ (Orcid ID: 0000-0002-0808-0151), Nedret ŞENGONCA TORT (Orcid ID: 0000-0002-8541-6376), Ege Üniversitesi Fen Fakültesi Biyoloji Bölümü, 35100, İzmir, Türkiye

*Sorumlu Yazar/Corrensponding Author: Aylin EŞİZ DEREBOYLU, e-mail: adereboylu@yahoo.com 


\section{GíRiş}

Ekonomisi tarıma dayalı olan ülkelerde, bakteri, fungus ve çeşitli yabani otlar ürün kalitesinde bozulmalara ve ürün kayıplarına neden olmaktadır. Pestisitlerin kullanıma girmesinden önce, çiftçiler zararlıların kontrolünde külfetli ve aynı zamanda ekonomik olmayan yöntemler kullanmaktaydı. Son 50 yılda ise kimyasal kontrol dünya çapında yaygın olarak kullanılmaya başlandı (Hock ve ark., 1991). Kimyasal savaşımın bir parçası olarak görülen pestisitler, düşük maliyeti, kullanım kolaylığı ve etkili olmaları nedeniyle zararlı kontrolünde ilk sırada yer almaktadırlar (Rabbinge ve Van Oijen, 1997) .

Modern pestisitler, özel bileşiklerdir ve hedef organizmalara karşı etki sağlamak amacıyla dizayn edilmişlerdir. Piretroit insektisitlerin artan kullanımı sadece toprakta birikim yapmaz. Bununla beraber bitki ve diğer hedeflenmeyen organizmalar üzerinde de zararlı etkilere neden olur. $\mathrm{Bu}$ da fitotoksisitelerinin tam olarak anlaşılmasını gerektirir (Bragança ve ark., 2018). Ancak yine de fungisit ve insektisitlerin fitotoksik etkileri tam olarak anlaşılmış değildir (Xia ve ark., 2006).

Yapılan bir çalışmada üç herbisit, üç fungisit ve üç insektisitin hıyar yaprakları üzerindeki fitotoksik etkileri araştırılmıştır. İnsektisit uygulamalarının net fotosentez oranında, stoma iletkenliğinde azalmaya neden olduğu görülmüştür. Ayrıca yapılan tüm pestisit uygulamalarının fotosentezi inhibe ettiği belirlenmiştir (Xia ve ark., 2006).

Organofosforlu bir pestisit olan Azinphos methyl, Medicago sativa L. bitkisine uygulanmış, uygulamadan 24 saat sonra klorofil içeriğinin kontrol grubuna göre azaldığı belirlenmiştir (Flocco ve ark., 2003).

Fidalgo ve ark. (1993)'nın yaptığı bir çalışmada, patates fidelerine Deltamethrin uygulanmış, bu maddenin nişasta miktarında azalmaya neden olduğu, aynı zamanda kloroplast gelişimini de inhibe ettiği rapor edilmiştir.

Asma (Vitis vinifera L.) bitkisine Botrytis cinerea fungusunun kimyasal kontrolünde kullanılan fludioxonil ve primethanil fungisitlerinin uygulanması sonucunda protein sentezinin teşvik edildiği, yani strese bağlı proteinlerin artmasina neden olduğu bildirilmiştir (Saladin ve ark., 2003).

Çalışmamızda, ülke ekonomisine önemli katkılar sağlayan hıyar (Cucumis sativus L.) bitkisinin bölgemizdeki üretimi esnasında kontrolsüz ve yaygın olarak kullanıldığı görülen Cypermethrin etken maddeli sentetik piretroit sınıfina giren bir insektisitin farklı konsantrasyonlarının hıyar bitkisi üzerine olası morfolojik ve fizyolojik etkileri araştırılmıştır.

\section{MATERYAL VE YÖNTEM}

Çalışmada İzmir- Menderes bölgesindeki seralarda en çok ekimi yapılan Gordion F1 hıyar çeşidi kullanılmıştır. İnsektisit olarak ise bu bölgede kullanıldığı belirlenen EC Cypermethrin etken maddeli sentetik bir piretroit seçilmiştir. Farkl1 konsantrasyonlarda uygulanan insektisitin çimlenme ve fide gelişimi üzerine etkilerini ortaya koymak amaciyla tohum çimlenmesi denemesi yapılmıştır. Çimlenme denemesi için, $9 \mathrm{~cm}$ çapındaki petriler içine çift kat filtre kağıdı konmuş ve her petriye 50'şer adet tohum gelecek şekilde (her grup için üç tekrarlı) 150'şer tohum kullanılmıştır. Petrilerdeki filtre kağıtlarına, kullanılan insektisitin etikette önerilen doz (0.4 $\left.\mathrm{ml} \mathrm{L}{ }^{-1} \mathrm{su}\right)$, önerilen dozun iki katı $\left(0.8 \mathrm{ml} \mathrm{L}^{-1} \mathrm{su}\right)$ ve üç katı $\left(1.2 \mathrm{ml} \mathrm{L}^{-1} \mathrm{su}\right)$ konsantrasyonları ile hazırlanan 10'ar $\mathrm{ml}$ çözelti uygulanmış, kontrol grubu ise sadece distile su ile ıslatılmıştır. Daha sonra tohumlar optimum çimlenme sıcaklığı olan $25 \pm 1{ }^{0} \mathrm{C}$ 'de fitotronda çimlenmeye bırakılmış, çimlenme yüzdeleri belirlenmiştir. Tohum çimlenme denemelerinde kontroller her gün aynı saatte olmak üzere (24., 48. ve 72 . Saatlerde) yapılmıştır. Petrilere tohumlar ekildikten 7 gün sonra çimlenmiş fidelerde 
koleoptil ve kök boyları ölçülmüş, gravimetrik olarak da yaş-kuru ağırlıkları belirlenmiştir.

Çalışmada kullanılan bitki materyali Ege Üniversitesi Ziraat Fakültesi Bitki Koruma Bölümü seralarından temin edilmiştir. Gordion F1 tohumlarından üretilen toplam 112 fide elde edilmiştir. Her uygulama grubu için 7'şer saksı ve her saksı için 4'er fide ayrılmıştır. İlk insektisit uygulaması bitkiler bir aylık olduğunda yapılmış ve etikette önerilen doz $\left(0.4 \mathrm{ml} \mathrm{L}^{-1} \mathrm{su}\right)$, önerilen dozun iki katı $\left(0.8 \mathrm{ml} \mathrm{L}^{-1} \mathrm{su}\right)$ ve üç katı $\left(1.2 \mathrm{ml} \mathrm{L}^{-1} \mathrm{su}\right)$ konsantrasyonlarda püskürtücü yardımıyla önerilen ve yaygın kullanım şekli dikkate alınarak 10 gün arayla 5 defa uygulanmıştır. Her uygulamada tüm yaprakların ıslanmasına dikkat edilmiştir. Kullanılan yöntemler dikkate alınarak son ilaçlamadan yaklaşık 2 gün sonra total protein ve prolin analizleri ile birlikte fotosentetik pigment maddeleri ve endogen hormon miktarlarını belirlemek üzere, her gruptan farklı bitkilerin aynı seviyelerindeki yaprakları alınmıştır.

Her analiz üçer tekrarlı olmak üzere Witham ve ark. (1971)'nın yöntemiyle fotosentetik

pigment maddelerinin tayini, Bradford (1976) yöntemiyle total proten tayini, Bates ve ark. (1973)'nın yöntemiyle de prolin analizi yapılmıştır. Sonuçların istatistiki değerlendirilmelerinde tek yönlü Anova ve Tukey (1980) testi kullanılmıştır.

\section{BULGULAR VE TARTIŞMA}

Farkl1 konsantrasyonlarda uygulanan insektisitin çimlenme üzerindeki etkileri değerlendirildiğinde ilk 24 saatin sonunda $0.4 \mathrm{ml}$ $\mathrm{L}^{-1}$ su uygulanan grupta 150 tohumdan 138 ' inin, $0.8 \mathrm{ml} \mathrm{L}^{-1}$ su uygulanan grupta $141^{\prime}$ inin, $1.2 \mathrm{ml}$ $\mathrm{L}^{-1}$ su uygulanan grupta ise $138^{\prime}$ 'inin çimlendiğ $\mathrm{i}$ görülmüştür. $\mathrm{Bu}$ süre sonunda kontrol grubunda 147 tohum çimlenmiştir. 48 saatin sonunda ise kontrol grubuyla beraber tüm uygulama gruplarındaki tohumların tamamının çimlendiği tespit edilmiştir. Çalışmada elde ettiğimiz bu veriler 1şı ğında 24 saatin sonunda oransal farklılıklar olmasına karşın, 48 saatin sonunda tüm tohumların çimlenmesi uygulanan insektisitin tohum çimlenmesi üzerinde önemli bir etkisinin olmadığını göstermiştir (Şekil 1).

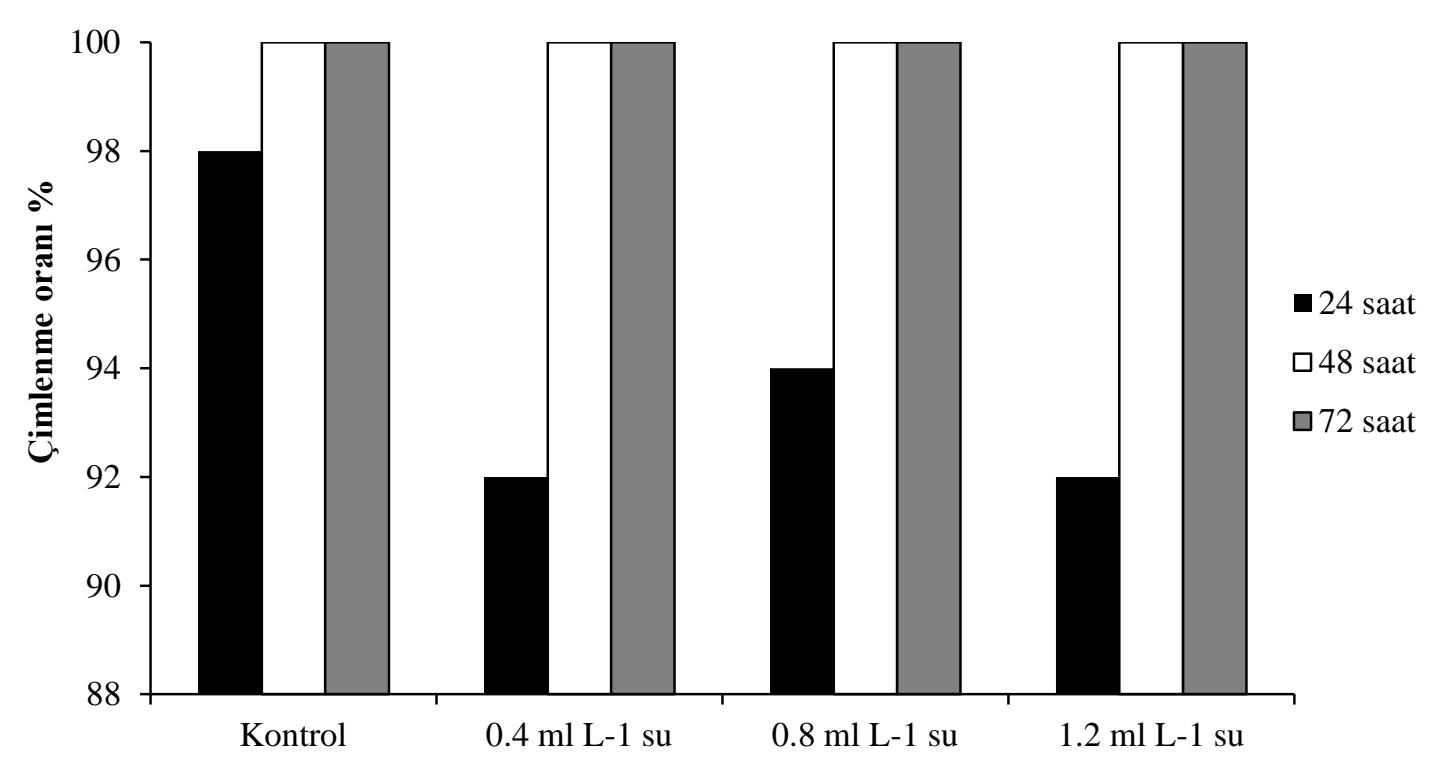

Şekil 1. Farklı konsantrasyonlarda yapılan insektisit uygulamalarının hıyar bitkisinin çimlenmesi üzerine etkisi 
İnsektisitin büyüme parametreleri üzerine etkileri incelendiğinde; Kök Yaş ağırlı̆̆ 1 ve Kök Kuru ağırlığı ile $0.4 \mathrm{ml} \mathrm{L}^{-1}$ su ve $0.8 \mathrm{ml} \mathrm{L}^{-1} \mathrm{su}$ uygulama grupları arasındaki pozitif ilişki anlamlı iken, $1.2 \mathrm{ml} \mathrm{L}^{-1}$ su uygulama grubu ile Kök Boyu, Kök Yaş Ağırlığı ve Kök Kuru ağırlığı arasındaki negatif ilişki istatistiksel açıdan anlamlı bulunmuştur. Diğer taraftan her üç uygulama grubu ile Koleoptil boyu, Koleoptil YA ve Koleoptil KA arasındaki pozitif ilişki istatistiksel açıdan anlamlıdır. Elde edilen pigment maddeleri miktarlarında kontrol grubuna göre özellikle Önerilen doz x3 (1.2 ml $\left.\mathrm{L}^{-1} \mathrm{su}\right)$ uygulama grubunda azalma olduğu görülmüştür ancak istatistiksel açıdan anlamlı bulunmamıştır (Çizelge 2). Protein ve Prolin değerlerindeki artış özellikle Önerilen doz x3 (1.2 $\left.\mathrm{ml} \mathrm{L}^{-1} \mathrm{su}\right)$ uygulama grubunda istatistiksel açıdan anlamlı görülmüştür (Çizelge 3). Bununla beraber Endogen IAA ve ABA miktarlarında, kontrol grubuna göre Önerilen doz x $3\left(1.2 \mathrm{ml} \mathrm{L}^{-1}\right.$ $\mathrm{su})$ uygulama grubunda görülen artış istatistiksel açıdan anlamlıdır (Çizelge 4).

Çizelge 1. Farklı konsantrasyonlarda yapılan insektisit uygulamalarının hıyar bitkisinin kök ve koleoptil gelişimi üzerine etkileri $(n=50)$

\begin{tabular}{ccccccc}
\hline & $\begin{array}{c}\text { Kök boyu } \\
(\mathbf{m m})\end{array}$ & $\begin{array}{c}\text { Koleoptil boyu } \\
(\mathbf{m m})\end{array}$ & $\begin{array}{c}\text { Kök YA } \\
(\mathbf{g})\end{array}$ & $\begin{array}{c}\text { Koleoptil YA } \\
(\mathbf{g})\end{array}$ & $\begin{array}{c}\text { Kök KA } \\
(\mathbf{g})\end{array}$ & $\begin{array}{c}\text { Koleoptil KA } \\
(\mathbf{g})\end{array}$ \\
\hline \multirow{2}{*}{ Kontrol } & 10.416 & 5.890 & $0.079 \pm$ & $0.145 \pm$ & $0.0020 \pm$ & $0.0179 \pm$ \\
& \pm 0.202 & \pm 0.774 & 0.022 & 0.023 & 0.0007 & 0.0056 \\
\multirow{2}{*}{$\mathbf{0 . 4} \mathbf{~ m l ~ L}^{-1} \mathbf{s u}$} & 11.168 & 6.768 & $0.113 \pm$ & $0.184 \pm$ & $0.0030 \pm$ & $0.0557 \pm$ \\
& \pm 0.221 & $\pm 0.560^{*}$ & $0.014^{*}$ & $0.025^{*}$ & $0.0004^{*}$ & $0.002^{*}$ \\
$\mathbf{0 . 8} \mathbf{~ m l ~ L}^{-1}$ su & 9.748 & 6.844 & $0.116 \pm$ & $0.186 \pm$ & $0.0050 \pm$ & $0.0577 \pm$ \\
& \pm 0.289 & $\pm 0.661^{*}$ & $0.019^{*}$ & $0.026^{*}$ & $0.0003^{*}$ & $0.0056^{*}$ \\
$\mathbf{1 . 2} \mathbf{~ m l ~ L ~ L ~}^{-1}$ su & 7.652 & 7.158 & $0.065 \pm$ & $0.202 \pm$ & $0.0018 \pm$ & $0.0737 \pm$ \\
& $\pm 0.286^{*}$ & $\pm 0.629^{*}$ & $0.014^{*}$ & $0.024^{*}$ & 0.0005 & $0.0023^{*}$ \\
\hline
\end{tabular}

“*” ve kontrol grubu arasındaki farklılık istatistik açıdan önemlidir $(\mathrm{p}<0.05)$. KA: Kuru ağırlık, YA: Yaş ağırlık

Çizelge 2. Farklı konsantrasyonlarda yapılan insektisit uygulamalarının hıyar bitkisinin fotosentetik pigment maddeleri üzerine etkisi $(n=4)$

\begin{tabular}{lccccc}
\hline & Kl a & Kl b & Kl a/b & Total Kl & Karotenoid \\
\hline Kontrol & $1.016 \pm 0.077$ & $0.400 \pm 0.021$ & $2.536 \pm 0.083$ & $1.416 \pm 0.097$ & $4.314 \pm 0.247$ \\
$\mathbf{0 . 4} \mathbf{~ m l ~ L}^{-\mathbf{1}}$ su & $1.110 \pm 0.135$ & $0.452 \pm 0.060$ & $2.461 \pm 0.120$ & $1.562 \pm 0.193$ & $4.598 \pm 0.552$ \\
$\mathbf{0 . 8} \mathbf{~ m l ~ L}^{-\mathbf{1}} \mathbf{~ s u}$ & $1.155 \pm 0.183$ & $0.700 \pm 0.327$ & $1.865 \pm 0.647$ & $1.855 \pm 0.488$ & $4.717 \pm 0.645$ \\
$\mathbf{1 . 2} \mathbf{~ m l ~ L}^{-\mathbf{1}} \mathbf{~ S u}$ & $1.011 \pm 0.148$ & $0.368 \pm 0.325$ & $2.744 \pm 0.587$ & $1.379 \pm 0.516$ & $4.3991 \pm 0.569$ \\
\hline
\end{tabular}

Çizelge 3. Hıyar bitkilerine farklı konsantrasyonlarda yapılan insektisit uygulamasının toplam protein ve prolin miktarları üzerine etkileri $(\mathrm{n}=4 ; \pm$ ortalamanın standart hatası)

\begin{tabular}{|c|c|c|}
\hline Uygulama Grupları & $\operatorname{Protein}\left(\mathrm{mg} \mathrm{ml}^{-1}\right)$ & Prolin $\left(\mathrm{mg} \mathrm{ml}^{-1}\right)$ \\
\hline Kontrol & $0.915 \pm 0.314$ & $0.724 \pm 0.098$ \\
\hline $0.4 \mathrm{ml} \mathrm{L}^{-1} \mathrm{su}$ & $1.504 \pm 0.462^{*}$ & $0.700 \pm 0.076$ \\
\hline $0.8 \mathrm{ml} \mathrm{L}^{-1} \mathrm{su}$ & $0.762 \pm 0.078$ & $0.751 \pm 0.102$ \\
\hline $1.2 \mathrm{ml} \mathrm{L}^{-1} \mathrm{su}$ & $1.553 \pm 0.324^{*}$ & $0.984 \pm 0.085^{*}$ \\
\hline
\end{tabular}

\footnotetext{
“*” ve kontrol grubu arasındaki farklılık istatistik açıdan önemlidir $(\mathrm{p}<0.05)$.
} 
Çizelge 4. Farklı konsantrasyonlarda yapılan insektisit uygulamalarının endogen IAA ve ABA miktarları üzerine etkisi $(\mathrm{n}=3 ; \pm$ ortalamanin standart hatas 1$)$

\begin{tabular}{ccc}
\hline \multirow{2}{*}{ Uygulama grupları } & \multicolumn{2}{c}{ Kantitatif Hormon Miktarı $(\boldsymbol{\mu g}$ g-1 doku) } \\
\cline { 2 - 3 } & IAA & ABA \\
\hline Kontrol & $8.350 \pm 0.756$ & $29.666 \pm 0.104$ \\
$\mathbf{0 . 4} \mathbf{~ m l ~ L}^{-1} \mathbf{~ s u}$ & $8.666 \pm 0.365$ & $34.066 \pm 0.166$ \\
$\mathbf{0 . 8} \mathbf{~ m l ~ L}^{-1} \mathbf{~ s u}$ & $8.133 \pm 0.477$ & $34.034 \pm 0.993$ \\
$\mathbf{1 . 2} \mathbf{~ m l ~ L}^{-1} \mathbf{~ s u}$ & $10.483 \pm 0.287^{*}$ & $35.133 \pm 0.923^{*}$ \\
\hline
\end{tabular}

“*” ve kontrol grubu arasındaki farklılık istatistik açıdan önemlidir $(\mathrm{p}<0.05)$.

Tarımsal ürünlerin korunmasında en çok başvurulan pestisit kullanımının, yüksek etkiye sahip olması, hızlı sonuç vermesi, ekonomik olması gibi avantajlarının yanında bilinçsiz ve kontrolsüz kullanımı sonucu olumsuz etkilerinin olabileceği, özellikle önerilen dozun aşılması durumunda bitkide biyotik strese neden olabileceği (Lewitt, 1980) yadsınamaz bir gerçektir.

Köse (1989)'nin yapmış olduğu bir çalışmada, Thiram, Mancozeb, Captan, Benomyl ile Ipradione pestisitlerinin hiyar tohumlarının çimlenmesini önemli ölçüde etkilemediği görülmüştür. Çalışmamızda da, çimlenme yüzdelerinde kontrol grubuna göre herhangi bir olumsuz etkilenme görülmemiştir (Şekil 1).

Pestisitlerin bitki büyüme ve gelişmesinde etken oldukları bilinmektedir. Bitkiler üzerinde çeşitli çevresel faktörlerin büyüme ve gelişme üzerinde en tipik etkisi kök büyümesini inhibe etmeleridir (Cramer ve ark., 1987; Eun ve ark., 2000). Sistemik bir fungisit olan Topsin M'nin yüksek konsantrasyonlarda uygulanmasının Vigna radiata L. wilezek ve Pennisetum americanum L. bitkileri üzerinde zararlı etkiler meydana getirdiği özellikle kök büyümesini inhibe ettiği (Siddiqui ve Khan, 2001), yine sistemik bir pestisit olan Benlat'ın de kök büyümesini inhibe edici özellikte olduğu (Siddiqui ve ark., 1999) rapor edilmiştir.

Yapılan bir çalışmada, Cucumis sativus L.cv "marketeer" bitkisine Alachlor ve Metachlor uygulanmış ve çimlenmeden 48 saat sonra radikula uzaması, kuru ve yaş ağırlıkların inhibe olduğu rapor edilmiştir (Sloan ve Camper, 1986). Başka bir çalışmada, chlorsulfuron ve metsulfuron methyl'in misir ve bezelye bitkilerine uygulandığında kök ve gövde büyümesini azalttıkları bildirilmiştir (Fayez ve ark., 1995).

Çalışmamızda farklı konsantrasyonlarda uygulanan insektisitin hıyar bitkisinde büyüme parametreleri üzerine etkileri incelendiğinde; kök boyu, yaş ve kuru ağırlık değerlerinin literatür verileriyle benzer şekilde kontrol grubuna göre azaldığı görülmüştür. $\mathrm{Bu}$ azalmanın özellikle önerilen doz x3 uygulama grubunda istatistiki olarak anlaml $\quad(p<0.05)$ olduğu bulunmuştur. Koleoptil boyu, yaş ve kuru ağırlıklarında ise kontrol grubuna göre artışlar olduğu saptanmıştır (Çizelge 1).

Toksik maddelerin etkisi, öncelikle bitki hücrelerinin en duyarlı fotosentetik kısımlarında olmakta ve daha sonra diğer enzimatik sistemler etkilenmektedir (Korte ve ark., 2000). Uygulanan toksikantların özellikle yüksek konsantrasyonlarının bitkide stres meydana getirdiği, klorofil miktarını azaltarak fotosentezi olumsuz yönde etkilediği, $\mathrm{CO}_{2}$ fiksasyonunu engellediği bilinmektedir (Hopkins, 1995). Stres teşvikli değişimler, yaprak alanında, pigment konsantrasyonunda, fotosentez oranı ve diğer büyüme parametrelerinde ve bitki gelişiminde azalma ile elde edilen üründe de kayılarla kendini göstermektedir (Bashir ve ark., 2006; Spiers ve ark., 2008). Yapılan bir çalışmada, Medicago sativa L. bitkisine organofosforlu bir pestisit olan Azinphos methyl uygulanmış, 
uygulamadan 24 saat sonra klorofil içeriğinin kontrol grubuna göre azaldığ 1 belirlenmiştir (Flocco ve ark., 2003). Diğer bir çalışmada düşük konsantrasyonda uygulanan insektisitin buğday yaprağındaki pigment içeriği ve fotosentez aktivitesinde artışa sebep olmasına karşın konsantrasyondaki artışla paralel olarak bu değerlerde azalma görüldüğü rapor edilmiştir (Kumar Pandey ve Gopal, 2011). Türky1lmaz Ünal ve Eşiz Dereboylu (2015) nun yaptığ çalışmada ise, iki farklı mısır kültüvarına (Sert misir Adapop 2 ve Cin misir Adapop 10) acetamiprid etken maddeli bir insektisit uygulanmış ve fizyolojik etkileri araştırılmıştır. Çalışmada en düşük klorofil miktarları Sert mısır önerilen doz grubunda elde edilmiştir. Karotenoid miktarlarında ise uygulamadan sonra sert misirda kontrole göre azalma, Cin misir da ise kontrol grubuna göre artış olduğu belirtilmiştir. Benzer şekilde Triact 70 insektisiti uygulanan Gerbera bitkilerinde fotosentez oranının önerilen doz x4 uygulama grubunda azaldığı rapor edilmiştir (Spiders ve ark., 2008).

Fotosentetik pigment maddelerine ilişkin bulgular Çizelge 2'de verilmiştir. Bu noktada; $\mathrm{Kla}, \mathrm{Kl} \mathrm{b}$ ve total $\mathrm{Kl}$ değerlerinde kontrole göre önerilen doz ve iki katı uygulamalarda bir artış olmuş ancak x3 uygulama grubunda azalma gerçekleşmiştir. Elde edilen veriler literatür verileriyle paralellik göstermektedir.

Birçok pestisitin kullanılması sonucunda fotosentez mekanizmasinı etkileyerek serbest oksijen radikallerinin açığa çıktığı düşünülmektedir. $\mathrm{Bu}$ serbest oksijen radikallerinin hücrelerde oksidasyona neden olmasını önlemek için strese maruz kalan toleranslı bitkiler Süperoksitdismutaz (SOD), peroksidaz (PO) ve katalaz enzimleri ile karotenoidler gibi çeşitli antioksidantları meydana getirmektedir (Edreva, 1998). Çalışmamızda da karotenoid değerlerinin kontrol grubuna göre artış gösterdiği görülmüştür (Çizelge 2).
Çevresel streslere verilen tepkiler hormonlar düzeyinde de incelenmiştir. Absisik asit (ABA), çevresel streslere karşı bitkilerin adaptasyonlarında önemli rol oynayan bir fitohormondur (La Rosa ve ark., 1987). Tuz stresi, kuraklık, yoğun pestisit uygulaması gibi çeşitli abiyotik stres faktörleri altında ABA seviyesinin arttığı bilinmektedir (Liotenberg ve ark., 1999). Yapılan bir çalışmada, uygulanan Captan fungisitinin biber bitkisinde içsel ABA miktarını kontrol grubuna göre arttırdığ belirlenmiştir (Tort ve Türkyılmaz, 2003). Yine fungisit uygulanan domates bitkilerinde IAA ve ABA miktarının kontrole göre artış gösterdiği rapor edilmiştir (Öztürk ve Tort, 2004). Ayrıca değişik stres koşullarının bitkilerde etilen sentezini arttırdığ 1 ve bunun da ABA sentezinin artmasına yol açtığı bildirilmiştir (Hananya ve ark., 1976). Aynı zamanda IAA'nın bitkide etilen sentezini hızlandırıcı bir faktör olduğu, stresle birlikte yapraklarda içsel IAA ve ABA miktarlarının arttı̆ğ, IAA düzeyindeki artışın ABA sentezini uyardiğ 1 rapor edilmiştir (Topçuoğlu ve Çakırlar, 1985).

Çalışmamızda da IAA ve ABA değerlerinin literatür bilgileriyle paralel olarak kontrol grubuna göre artış gösterdiği görülmüştür (Çizelge 4).

Farklı abiyotik faktörler bitkideki osmotik stresi, oksidatif stresi ve protein denaturasyonunu uyarabilir. $\mathrm{Bu}$ da reaktif oksijen türlerinin temizleme sisteminin hızlanması, stres proteinlerinin indüksiyonu, uygun bileşiklerin birikimi gibi benzer hücresel tepkilere yol açabilir (Zhu, 2002). Bitkilerde strese verilen cevaplardan biri uygun organik bileşiklerin farklı tiplerinin üretimidir (Serraj ve Sinclair, 2002). Genellikle bu tür bileşikler stres koşullarında bitkiyi korurlar (Bohnert ve Jensen, 1996). Bu bileşiklerden en önemlileri prolin, sukros, polioller, glisin betain vs.'dir (Hsu ve ark., 2003; Kavi Kishore ve ark., 2005).

Kullanılan insektisitler de, bitkilerin büyüme unsurlarını, çeşitli metabolik aktivitelerini 
etkileyerek, bitki hücrelerinde oksidatif strese sebep olabilirler (Toscano ve ark., 1982; Jones ve ark., 1986). Pestisit uygulanmış bitkilerde artan prolin birikimi, çevresel streslere karşı verilen bir cevap olarak nitelendirilmektedir (Alia ve ark., 1994). 45 günlük soya fasülyesi bitkilerine çeşitli deltamethrin (sentetik piretroit insektisit) konsantrasyonları sprey yoluyla uygulanmış, ve antioksidatif savunma sistemi üzerindeki etkileri araştırılmıştır. Araştırma sonuçlarına göre, lipid peroksidasyon, prolin ve total glutatyon içeriğinde artış gözlenmiştir (Bashir ve ark., 2006). Yapılan bir başka çalışmada, diuron herbisitinin farklı konsantrasyonlarının soya fasülyesi kültür çeşitlerinde prolin miktarı artışına neden olduğu ortaya konmuştur (Fayez, 2000). Ayrıca bir diğer çalışmada, misır bitkilerine acetamiprid uygulamasının prolin içeriğinde artışa neden olduğu da rapor edilmiştir (Türkyılmaz Ünal ve Eşiz Dereboylu, 2015).

Biyotik ve abiyotik çeşitli çevresel streslere karşı bitkilerin potansiyel reaksiyonlarından biri de spesifik peptidlerin ve proteinlerin artmasıdır (Przymusiński ve ark., 2004). Pestisit uygulamalarının protein sentezini teşvik ettiği, stres proteinlerinin oluşumuna neden olduğuna dair pek çok çalışma yapılmıştır (Scarponi ve ark., 2002; Saladin ve ark., 2003). Asma bitkisine (Vitis vinifera L.), fludioxonil ve primethanil fungisitlerinin uygulanmasıyla protein sentezinin teşvik edildiği yani strese bağlı proteinlerin artmasina neden olduğu bildirilmiştir (Saladin ve ark., 2003).

Toplam prolin ve protein miktarlarına ilişkin bulgularımız incelendiğinde; protein ve prolin miktarlarının kontrol grubuna göre özellikle önerilen doz x3 uygulama gruplarında istatistiki olarak da anlamlı $(p<0.05)$ artışlar gösterdiği görülmüştür. Elde edilen veriler literatür bilgileriyle de paralellik göstermektedir.

\section{SONUÇ}

$\mathrm{Bu}$ çalışma sonucu elde edilen veriler, özellikle önerilen doz x3 pestisit uygulamasında hıyar bitkisinin kök büyümesi ve pigment madde miktarında azalma, protein ve prolin miktarları ile içsel hormon içeriklerinde artış olduğunu göstermiştir. $\mathrm{Bu}$ sonuçlar tarımsal ürünleri hastalıklara karşı korumak amacıyla kullanılan pestisitlerin, bitkilerin fizyolojik yapılarını da etkilediğini göstermektedir. Tarımsal üretim esnasında çevreyi ve insan sağlı̆̆ını korumanın ön planda olduğu günümüzde, toksik etkili olabilen bu kimyasalların kullanımının kontrollü bir şekilde yapılması ve yüksek dozlarda kullanımının bitkiye verdiği zarar konusunda üreticilerin uyarılması büyük önem taşımaktadır.

Sonuç olarak; bu kimyasalların daha doğru kullanımı, alternatif uygulamalarla desteklenmesi, en önemlisi bu konuda verilecek eğitim ve piyasa denetiminin geliştirilmesi zorunlu hale gelmektedir.

\section{KAYNAKLAR}

Alia K, Prasad VSK, Pardhasaradhi P, 1994. Effect of zinc on free radicals and proline in Brassica and Cajanus. Phytochemistry, 39, 45-47.

Ashraf M, Foolad MR, 2007. Roles of glycine betaine and proline in improving plant abiotic stres resistance. Environmental and Experimental Botany, 59: 206-216.

Bashir F, Mahmooduzaffar, Siddiqi TO, Iqbal M, 2007. The antioxidative response system in Glycine max (L.) Merr. exposed to Deltamethrin, a synthetic pyrethroid insecticide. Environmental Pollution, 147(1): 94-100.

Bates LS, Waldren RP, Tevre IU, 1973. Rapid determination of free proline for waterstress studies. Plant and Soil, 39, 205-207.

Bohnert HJ, Jensen RG, 1996. Strategies for engineering water-stress tolerance in plants. Trends in Biotechnology, 14, 89-97. 
Bradford M, 1976. A rapid and sensitive method for the quantitation of microgram quantities of protein utilizing the principle of protein dye binding. Analytical Biochemistry, 72, 248-254.

Bragança I, Lemos PC, Barros P, Delerue-Matos C, Domingues VF, 2018. Phytotoxicity of pyrethroid pesticites and its metabolite towards Cucumis sativus. Science of The Total Environment, Apr 1;619-620:685-691, doi: 10.1016/j.scitotenv.2017.11.164.

Cramer GR, Lynch J, Lauchli A, Epstein E, 1987. Influx of $\mathrm{Na}^{+}, \mathrm{K}^{+}$and $\mathrm{Ca}^{2+}$ into roots of saltstressed cotton seedlings: effects of supplemental $\mathrm{Ca}^{2+}$. Plant Physiology, 83: 510-516.

Edreva A, 1998. Molecular bases of stres in plants. Bitkilerde Stres Fizyolojisinin Moleküler Temelleri Sempozyumu, 22-26 Haziran, E.Ü. Ziraat Fakültesi, E.Ü. Bilim-Teknoloji Uygulama ve Araştırma Merkezi, Bornova-İzmir, 234 s.

Eun SO, Youn HS, Lee Y, 2000. Lead disturbs microtubule organization in the root meristem of Zea mays. Physiologia Plantarum, 110: 357-365.

Fayez KA, 2000. Action of photosynthetic Diuron herbicide on cell organelles and biochemical constituents of the leaves of two soybean cultivars. Pesticide Biochemistry and Physiology, 66: $105-115$.

Fayez KA, Gerken I, Kristen Y, 1995. Ultrastructural responses of root caps to the herbicides chlorsulfuron and metsulfuron methyl, In: Baluska, F., et al. (eds.): Structure and Function of roots. Kluwer Acad. Publ., 277-287.

Fidalgo F, Santos I, Salema R, 1993. Effects of deltamethrin on field grown potato plants; Biochemical and ultrastructural aspects. Annals of Botany, 72, 263-267.

Flocco CG, Gorranza MP, Carvajal LG, Loewy RM, Rechen de D'Angelo AM, Giulietti AM, 2004. Removal of azinphos methyl by alfaalfa plants (Medicago sativa L.) in a soil-free system. The Science of the Total Environment, 327(1-3): 3139.
Hananya EB, Goldschmidt EE, Goren R, 1976. Ethylene Induced Formation af $\mathrm{ABA}$ in Citrus Pell as related to chloroplast transformations. Plant Physiology, 58: 377-399.

Hock WK, Day LG, Morley AW, 1991. Farm Chemicals Manual: A Guide to Safe Use and Handling. The Agric. And Vet. Chem. Assoc. Aust, Ltd.

Hopkins WG, 1995. Introduction to plant physiology. John Willey and Sons., Inc., USA, 464 p.

Hsu SY, Hsu YT, Kao CH, 2003. The effect of polyethylene glycol on proline accumulation in rice leaves. Biologia Plantarum, 46, 73-78.

Jones VP, Toscano NC, Johnson MW, Welter SC, Younman RR, 1986. Pesticide effect on plant physiology: integration into a pest management program. Bulletin of the Entomological Society of America, 32, 103-109.

Kavi Kishore PB, Sangam S, Amrutha RN, Laxmi PS, Naidu KR, Rao KRSS, Rao S, Reddy KJ, Theriappan P, Sreenivasulu N, 2005. Regulation of proline biosynthesis, degredation, uptake and transport in higher plants: its implications in plant growth and abiotic stres tolerance. Current Science Association, 88, 424-438.

Korte F, Kvesitadze G, Ugrekhelidze D, Gordezian M, Khatisashvili G, Buodze O, Zoalishvili G, Coulston F, 2000. Organic toxicants and plants. Ecotoxicology and Environmental Safety, 47: 126.

Köse N, 1989. Bazı Çökerten Etmenleriyle Kimyasal Savaşım Üzerinde Çalışmalar. Yüksek Lisans Tezi, Bornova-İzmir.

Kumar Pandey J, Gopal R, 2011. Laser-Induced chlorophyll fluorescence: A technique for detection of dimethoate effect on chlorophyll content and photosynthetic activity of wheat plant. Journal of Fluorescence, 21: 785-791.

La Rosa PC, Hasegawa PM, Rhodes D, Clithero JM, Watad AEA, Bressan RA, 1987. Abscisic acid stimulated osmotic adjustment and its involvement in adaptation of tobacco cells to $\mathrm{NaCl}$. Plant Physiology, 85: 174-181. 
Lewitt J, 1980. Responses of plants to environmental stresses. 1 : 3-18 Academic press, New York, U.S.A.

Liotenberg S, North H, Marion-poll A, 1999. Molecular biology and regulation of abscisic acid biosynthesis in plants. Plant Physiology and Biochemistry, 37 (5): 341-350.

Öztürk İ, Tort N, 2004. Fungisit Uygulamasının Domates (Lycopersicon esculentum Mill.) Bitkisi Yapraklarında Bazı Fotosentetik Pigment Maddeleri, Bitkisel Hormonlar ve Protein Miktarları Üzerine Etkisi. C.Ü. Fen-Edebiyat Fakültesi Fen Bilimleri Dergisi, 25: 1, 7-19.

Przymusiński R, Rucińska R, Gwóźdź EA, 2004. Increased accumulation of pathogenesis-related proteins in response of lupine roots to various abiotic stres. Environmental and Experimental Botany, 52: 53-61.

Rabbinge R, Van Oijen M, 1997. Scenario studies for future agriculture and crop protection. European Journal of Plant Pathology, 103: 197-201.

Saladin G, Magne C, Clement C, 2003. Physiolgical stres responses of Vitis vinifera $\mathrm{L}$. to the fungicides fludioxonil and pyrimethonil. Pesticide Biochemistry and Physiology, 77: 125-137.

Scarponi L, Vischetti C, Hassan NM, 2002. Effects of Propachlor on the formation of carbonhydrates and proteins in Vicia faba and the response of its defence mechanism. Agrochimica, 156: 165-175.

Serraj R, Sinclair TR, 2002. Osmolyte accumulation: can it really help increase crop yield under drought conditions? Plant Cell \& Environment, $25,333-341$.

Siddiqui ZS, Ahmed S, Stres A, 1999. Effect of systemic fungicides on germination, seedling growth, DNA, RNA and phenolic content of Brassica compestris L., Pakistan Journal of Biological Sciences, 2(4): 1350-1351.

Siddiqui ZS, Khan S, 2001. Effect of systemic fungicides and insecticides on absorption spectra, chlorophyll and phenolic contents of Vigna radiata L.Wilczek. Pakistan Journal of Biological Sciences, 4(7): 812-814.
Sloan ME, Camper ND, 1986. Effects of alachlor and metolachlor on cucumber seedlings. Environmental and Experimental Botany, 26 (1): 1-7.

Spiers JD, Davies FT, He C, Heinz KM, Bogran CE, Starman TW, 2008. Do insecticides affect plant growth and development?- (Research tests foliar insecticides to determine whether applications affect development in gerbera daisies). Greenhouse Grower, February, Vol:2.

Steel RGD, Torrie JH, 1980. Principles and Procedures of Statistics. Pp. 403-447. 2nd Ed. McGraw-Hill Inc., New York.

Topçuoğlu ŞF, Çakırlar H, 1985. Tuz Stresi Koşulunda Bitkilerde Absisik Asit (ABA) ve Sitokinin Miktarının Değişimi ve Bunun Fizyolojik Olaylar Üzerine Etkileri. Doğa Bilim Dergisi, Seri $A_{2}$ cilt: 9, sayı: 2.

Tort N, Türkyılmaz B, 2003. Physiological effects of captan fungicide on pepper (Capsicum annuит L.) plant. Pakistan Journal of Biological Sciences, 6(24): 2026-2029.

Toscano NC, Sances FV, Johnson MW, Lapre LF, 1982. The effect of various pesticides on lettuce physiology and yield. Journal of Economical Entomology, 75, 738-741.

Turkyılmaz Unal B, Esiz Dereboylu A, 2015. Some physiological effects of acetamiprid on two cultivars of corn plants. \$yton, International Journal of Experimental Botany, 84, 144-147.

Witham FH, Blaydes DF, Deulin RM, 1971. Experiments in Plant Physiology. Van Nostrand Reinhold Company, New York, 245 p.

Xia XJ, Huang YY, Wang L, Huang LF, Yu YL, Zhou YH, Yu JQ, 2006. Pesticides-induced depression of photosynthesis was alleviated by 24-epibrassinolide pretreatment in Cucumis sativus L. Pesticide Biochemistry and Physiology, 86:42-48.

Zhu JK, 2002. Salt and drought stres signal transduction in plants. Annual Review of Plant Biology, 53, 247-273. 